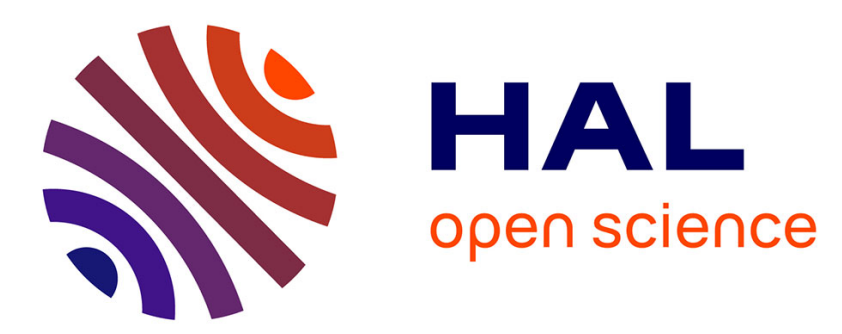

\title{
Real-Time Distributed Systems Control and Energy Management Using a Multi-Agent Technologies
}

Mohamed Azeroual, Tijani Lamhamdi, Hassan El Moussaoui, Hassane El Markhi

\section{- To cite this version:}

Mohamed Azeroual, Tijani Lamhamdi, Hassan El Moussaoui, Hassane El Markhi. Real-Time Distributed Systems Control and Energy Management Using a Multi-Agent Technologies. International Meeting on Advanced Technologies in Energy and Electrical Engineering IMAT3E'18, Nov 2018, FEZ, Morocco. hal-01941495

\section{HAL Id: hal-01941495 \\ https://hal.science/hal-01941495}

Submitted on 1 Dec 2018

HAL is a multi-disciplinary open access archive for the deposit and dissemination of scientific research documents, whether they are published or not. The documents may come from teaching and research institutions in France or abroad, or from public or private research centers.
L'archive ouverte pluridisciplinaire $\mathbf{H A L}$, est destinée au dépôt et à la diffusion de documents scientifiques de niveau recherche, publiés ou non, émanant des établissements d'enseignement et de recherche français ou étrangers, des laboratoires publics ou privés. 
IMAT3E'18

International Meeting on Advanced Technologies in Energy and Electrical

Engineering

\title{
Real-Time Distributed Systems Control and Energy Management Using a Multi-Agent Technologies
}

Azeroual Mohamed, Lamhamdi Tijani, El Moussaaoui Hassan and El Markhi Hassane

The Signals, Systems and Components Laboratory, Sidi Mohamed Ben Abdellah University, FST Fez, Morocco

*Email: Mohamed.azeroual1@usmba.ac.ma

\begin{abstract}
The microgrids distribution systems are a promising means to broadly the distributed energy resource (DER) systems integration. However, the optimal energy management and control of many energy generators, loads, and local storage units of microgrid present as an important challenge. The concept with multi-agent intelligent control may become a viable solution for smart grid and microgrid architecture. In this paper, the implementation of the distributed energy management and control strategy of a smart microgrid by an intelligent multi-agent system (MAS) approach to achieve multiple objectives in real-time is proposed. The MAS proposed is built with a co-simulation platform which the microgrid model, simulate using MATLAB/Simulink, and controlled by a MAS implemented in JADE through a middleware MACSimJX. The main study is to develop a new approach, to control the microgrid during the fault in the main grid and energy management.
\end{abstract}

Key words: Smart grid, Microgrid, Multi-agent system (MAS), Distributed Energy Resources (DER), MacsimJX, Renewable energy.

\section{Multi-agent framework for microgrid control}

The smart grid is an opportunity to use new information and communication technologies (ICTs), represents a transition towards an intelligent and digital technology that is used to supply electricity to consumers via two-way of communication and electric energy [1]. A microgrid is a construction block of smart grid and is a modern type of power system, the low voltage network, usually located at the consumer's side, storage 
IMAT3E'18

International Meeting on Advanced Technologies in Energy and Electrical

Engineering

system, control units, and the distributed generators, including wind power, solar, fuel cells, micro-turbines, and hydroelectric [2].

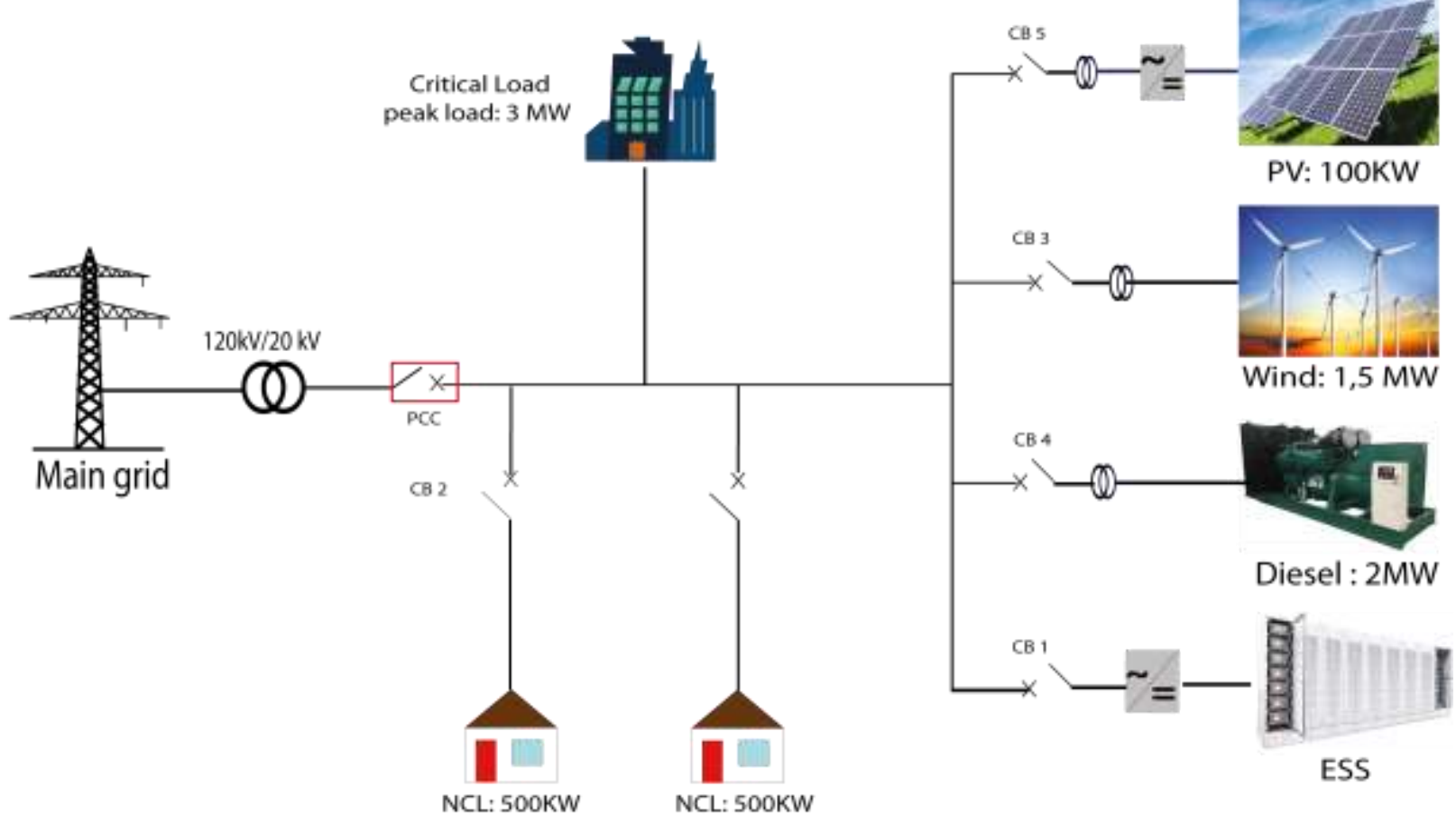

Figure 1. Microgrid architecture.

The studied microgrid is a power system that combines multiple Distributed Energy Sources (DER), critical and non-critical loads, and energy storage system (ESS) (Figure 1). The energy storage systems are assuring the increases of the RES integration issue and are able to provide or to store the difference between generated power and the consumption power. The architecture for microgrid coordinated control and energy management is controlled by MAS. There are four different type of agents: Load Agent, DER Agent, control Agent, and ESS Agent. Every agent has its specific functions, characters, and provides different services, each agent communicated with other agents and manages its assigned asset according to specified objectives (Table 1).

Table 1. Microgrid Agents tasks.

\begin{tabular}{|c|c|}
\hline Agent & \multicolumn{1}{c|}{ Tasks } \\
\hline Control Agent & $\bullet \begin{array}{l}\text { Is responsible for controlling microgrid operation } \\
\text { modes, monitoring, scheduling and managing its } \\
\text { subordinate agents }\end{array}$ \\
\hline
\end{tabular}


IMAT3E'18

International Meeting on Advanced Technologies in Energy and Electrical

Engineering

\begin{tabular}{|c|c|}
\hline & $\begin{array}{l}\text { - Supervising the state of the microgrid, connect or } \\
\text { disconnect MG to the main power grid at PCC. } \\
\text { - Receives from Simulink the difference signal } \\
\text { between the DER production and the loads' } \\
\text { consumption }\end{array}$ \\
\hline DER Agent & $\begin{array}{l}\text { - Collect information related to the energy source } \\
\text { such as availability, connection status, power } \\
\text { produced in real time. }\end{array}$ \\
\hline Load Agent & $\begin{array}{l}\text { - Receives from Simulink the critical load } \\
\text { consumption and the non-sensitive load } \\
\text { consumption. } \\
\text { - Collect information of power such as load power, } \\
\text { voltage, current. } \\
\text { - Is responsible to monitor and control load and } \\
\text { varying power consumption by load, }\end{array}$ \\
\hline ESS Agent & $\begin{array}{l}\text { - Receives the proposal to provide or to store } \\
\text { energy from the microgrid control agent. } \\
\text { - Collect the state of charge value of storage unit } \\
\text { from Simulink. }\end{array}$ \\
\hline
\end{tabular}

\section{Références}

1. GUNGOR, et al. 2013, “A survey on smart grid potential applications and communication requirements". IEEE Transactions on Industrial Informatics.

2. Khan, M. W., \& Wang, J. (2017). The research on multi-agent system for microgrid control and optimization. Renewable and Sustainable Energy Reviews, 80, 1399-1411. 